\title{
Perspectives of Waste Electrical and Electronic Equipment in Tampico, Mexico
}

\author{
René Bernardo Elías Cabrera-Cruz', María Esther Bautista-Vargas', \\ Julio César Rolón-Aguilar1, Ricardo Tobías-Jaramillo', Alberto José Gordillo-Martínez² \\ ${ }^{1}$ Division of Postgraduate Studies and Research, Faculty of Engineering “Arturo Narro Siller”, Autonomous \\ University of Tamaulipas, Tamaulipas, Mexico \\ ${ }^{2}$ Center for Chemical Research, Autonomous University of the State of Hidalgo, Pachuca, Mexico \\ Email: rcabreracruz@uat.edu.mx
}

Received 11 July 2014; revised 8 August 2014; accepted 2 September 2014

Copyright (C) 2014 by authors and Scientific Research Publishing Inc.

This work is licensed under the Creative Commons Attribution International License (CC BY).

http://creativecommons.org/licenses/by/4.0/

(c) () Open Access

\begin{abstract}
Waste electrical and electronic equipment (WEEE) has brought negative effects to the environment produced by the materials that compose them. The proper implementation of management plans of WEEE should integrate measures to prevent, mitigate and correct these affectations. As an initial step, it is necessary to make a diagnosis of the current situation of WEEE management which is the objective of this work. The studied zone was composed by the municipalities of Tampico, Ciudad Madero and Altamira located in southeast Tamaulipas, Mexico. The descriptive analysis of technical and regulatory aspects of the current management system in the study area was developed, including generation rates and analysis of waste streams. Among the main results, the generation of WEEE was estimated in 2040.38 tons/year for 2013 , distributed in the municipalities of Tampico with 830.93 tons/year, Altamira with 650.18 tons/year, and Ciudad Madero with 559.27 tons/year. This calculation was estimated using Mexico's WEEE generation indicators. The analysis of waste streams includes five categories of WEEE, Televisions with $61 \%$ of the total generation, followed by sound devices with $18 \%$, personal computers with $17 \%$; mobile phones with $2 \%$ as well as fixed phones with $1 \%$. In the study area, reports of Tampico's municipality indicated that 96 tons of WEEE was collected in the city of Tampico in 2013. In México, the national legislation considers WEEE in the category of waste requiring special handling (WRSH), however, an inadequacy exists in the environmental laws about the specific classification of this kind of debris that makes their effective management more difficult. No companies who provide a management or treatment operations for WEEE are reported in Tampico, or in the near region. In addition, despite an initial interest for the municipality to attend the WEEE problematic, a lack of sensibility of the population exists in the absence of environmental education programs.
\end{abstract}

\section{Keywords}

WEEE, Management, Tampico, EIA

How to cite this paper: Cabrera-Cruz, R.B.E., Bautista-Vargas, M.E., Rolón-Aguilar, J.C., Tobías-Jaramillo, R. and GordilloMartínez, A.J. (2014) Perspectives of Waste Electrical and Electronic Equipment in Tampico, Mexico. Journal of Environmental Protection, 5, 1266-1276. http://dx.doi.org/10.4236/jep.2014.512120 


\section{Introduction}

Electric and Electronic Equipment (EEE) who have reached the end of its useful life are known as Waste Electrical and Electronic Equipment (WEEE). Actually, these waste streams have taken relevance for its growing generation rates, among other reasons for the acquisition of technological innovations and the obsolescence in the design of EEE [1] [2]. The United Nations Environmental Program (UNEP), estimated a generation of about 20 to 50 million tons per year (tons/year) of WEEE worldwide [3] [4], whilst in the European Economic Community (EEC) is estimated 8 million tons/year, and Latin America had a gen ratio approximately of 120,000 tons/year in 2009. For the last region, the generation is expected to be triplicate in 2015. In 2010, Mexico reported a generation of 300,000 tons, approximately $2.7 \mathrm{~kg}$ of WEEE per capita per year [5] [6].

WEEE's sustained growth has brought adverse health effects in the population and the environment, caused by the toxic substances that are present in WEEE, estimated around $2 \%$ of the total weight of the waste. Such substances include polychlorinated biphenyls (PCB), Polybrominated diphenyl ethers (PBDEs), polychlorinated dibenzo (p) dioxins and furans (PCDD/Fs; “dioxins”), mercury, lead or cadmium, among others. The main effects reported included from cancer, bio-accumulating substances, damage to ecosystems, emission of gases such as dioxins, furans and others [7] [8]. For the mitigation of the adverse impacts of an uncontrolled disposal, some components of WEEE have a possible recycling potential and there are potential economic markets for them [1] [9]. Nevertheless, these options have been developed differently around the world. In Europe, only 25\% of WEEE are treated for recycling whereas in United States less than 20\% of WEEE receives a treatment or at less, recovery of materials. In Latin America, the incipient recycling of WEEE is carried out informally being the new initiative of formal recovery of WEEE materials [10]. In Mexico, the reported formal recycling capacity is about $10 \%$ of the total of WEEE generation ratio, with about $20 \%$ in the informal recycling market [11].

Basel Convention and Stockholm Convention on Persistent Organic Pollutants have unified criteria in the cross-border flow of toxic substances that integrate WEEE [12]-[14]. This situation has led to the development of environmental policies for proper management of WEEE, with criteria of mitigation and prevention in countries such as Switzerland, countries members of the EEC, Japan, among others [15]. Those policies specify actions for reducing toxic components from manufacturing and the involvement of all actors in the value chain [16] [17]. In Mexico, there is no specific regulation for WEEE. The General Law for the Integral Waste Management (LGPGIR, for its acronym in Spanish) considers WEEE as a category of waste requiring special handling [18]. Mexican Official Standard, NOM-161-SEMARNAT-2011, establishes criteria for classifying waste requiring special handling (WRSH) in a list in very general terms [19]. This generality in the classification hinders the management of WEEE. The LGPGIR establishes the need to formulate state WEEE management policies and plans and programs for the integrated management. In a management plan, it is essential to know generation ratios, recycling scenarios, waste streams and final disposal conditions. In this paper, the current management actions of WEEE are described in urban areas of southeast of Tamaulipas, Mexico with the aim of obtaining the basis for the development of a management plan integrating technical, economic, regulatory, social and institutional characteristics in the municipalities of Tampico, Madero City and Altamira, Tamaulipas, Mexico. These cities conform to the South Tamaulipas Conurbation Area which is included in the top ten regional economies in the country and without an efficient management of WEEE.

\section{Method}

This study was developed during 2012-2013 period at the Autonomous University of Tamaulipas, in the Tampico-Madero Campus located in Tampico City, Tamaulipas, Mexico. The methodology used was adapted of the criteria of Mexico's national diagnosis and the studies conducted in Mexico in recent years [3] [6] [11]. Results are obtained by the use of Battelle type indicators of environmental quality status, establishing evaluation criteria and estimation of WEEE per capita considering income levels based on the use of EEE. This work was conducted in four stages: description of the studied zone, generation ratio, waste stream analysis, recycling scenarios and final disposal of WEEE. In addition, actions for recovery and disposal of the study area were described.

\subsection{Stage 1: Description of the Studied Zone and Generation Ratios}

a) Description of the studied zone. The selection of appropriate boundaries is important for the development 
of a study of this type. Three options are distinguished, such as physical-natural or induced boundaries (hydrological basins, mountain ranges, coastlines, rivers, rugged peaks, roads, railways, canals, etc.), political-legal (public health districts, census tracts, areas of air quality control, etc., City Limits, region, state or province), finally, economic boundaries (industrial areas, mining districts, areas of economic development districts water collection/sewer/waste). For this work, a political boundary was chosen, selecting the municipalities of Altamira, Madero City and Tampico, located in the state of Tamaulipas, Mexico. With this regionalization key environmental factors were determined by desk studies on the environmental characteristics of the selected municipalities. These characteristics were divided between the physical sphere (inert and biotic) and anthropogenic sphere. This classification is adopted to establish the quality studies and environmental impact and management models of pollutants such as WEEE. In the studied zone lives a population of 751,285 persons [20], distributed in the municipalities of Altamira, Madero City and Tampico and it's located between the coordinates UTM X 625209 y 567 394; Y 2521960 y 2456235 (Figure 1) at the southeast of the state of Tamaulipas. The conurbation is bordered on the north and northwest by the municipalities of Aldama and Gonzalez; at the east by Aldama and the Mexico's Gulf; and in the south limits with the state of Veracruz with Panuco River as natural border [20] [21]. Figure 2 shows land use in the municipalities of Tampico and Madero City (mainly urban), while in Altamira is mostly rural and only $4 \%$ urban. Economic activity in the study area is mainly based on related petroleum products such as oil refining that takes place in Madero City. In Tampico, trade and services as commercial port, commercial, industrial, tourism and fishing are relevant. Furthermore, Altamira is considered one of the most important industrial ports in Mexico [21].

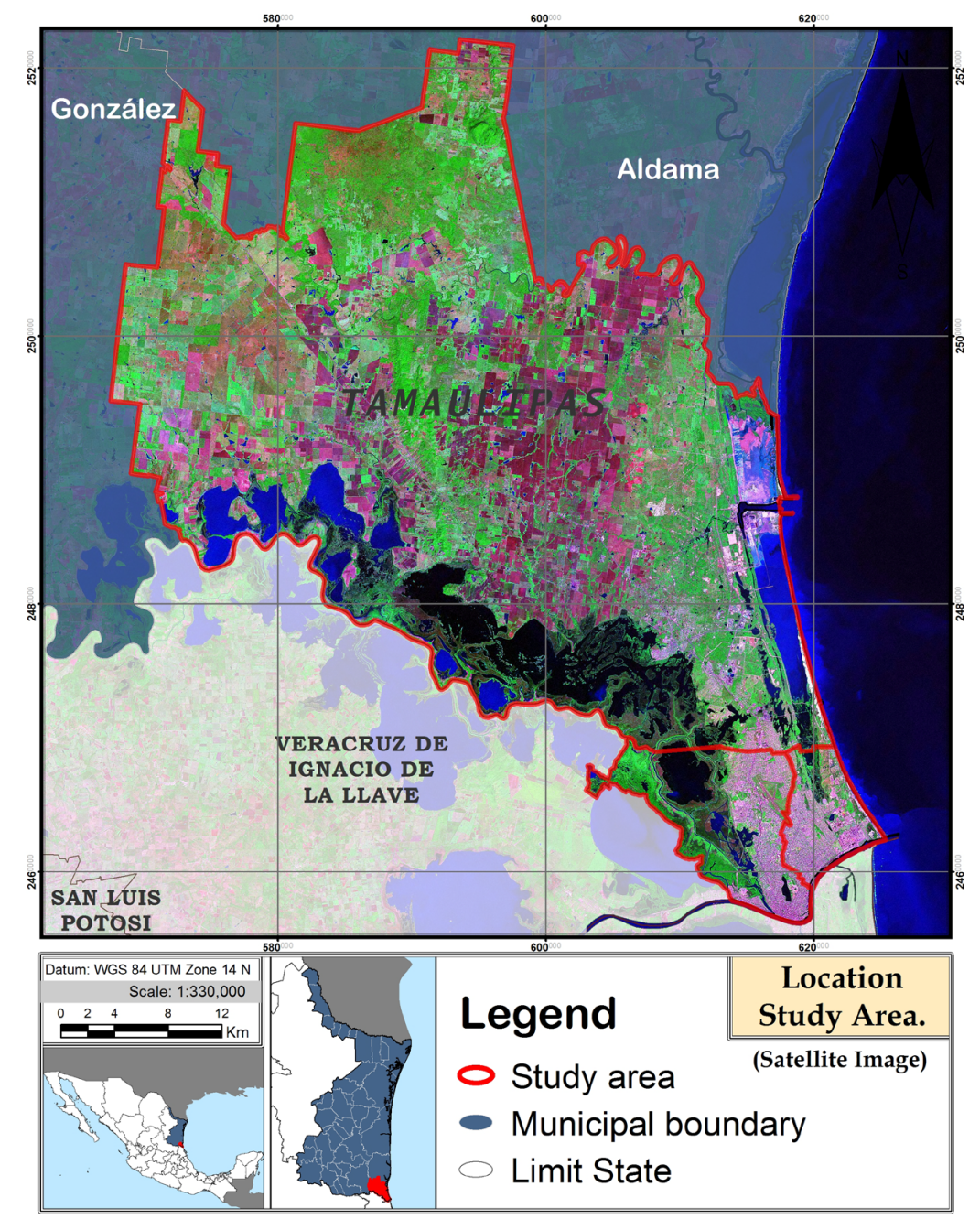

Figure 1. Location of the study area. 


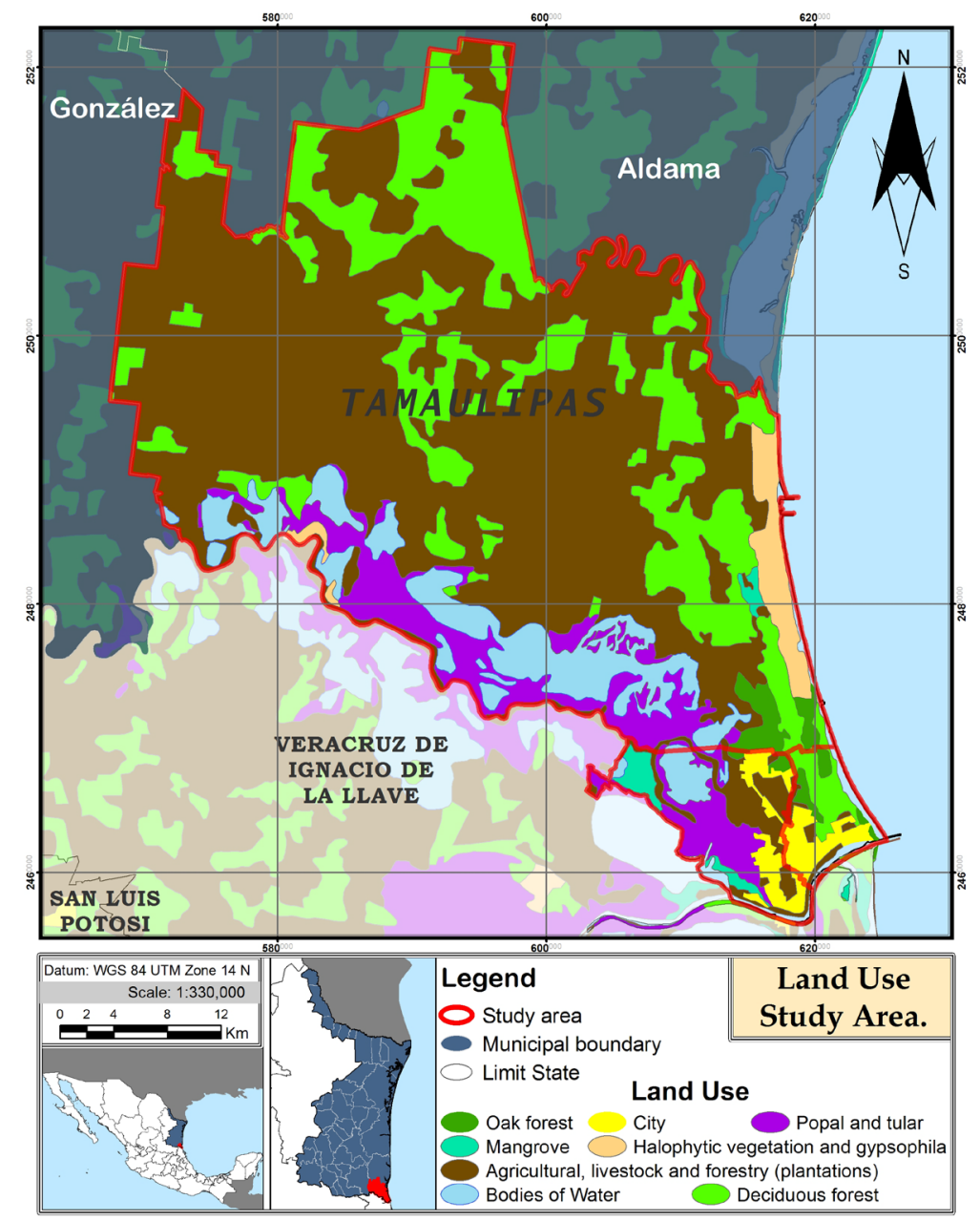

Figure 2. Land use study area.

b) Estimation of generation ratios. It was used a statistical tool of extrapolation of data using Microsoft Excel, due to the ease of use and availability. The linear extrapolation creates a tangent line at the end of the known data and extending it beyond that limit. If the two points closest to the point $x_{*}$, to be extrapolated are $\left(x_{k-1}, y_{k-1}\right)$ y $\left(x_{k}, y_{k}\right)$, linear extrapolation function creates (1). You can include more than two points and average slope of the linear interpolant, by regression techniques on data points to be included. This is similar to the linear prediction [22] [23].

$$
y\left(x_{*}\right)=y_{k-1}+\frac{x_{*}-x_{k-1}}{x_{k}-x_{k-1}}\left(y_{k}-y_{k-1}\right)
$$

The projections of population growth by the National Population Council (CONAPO, acronym in Spanish) were considered for estimate the population during the period 2006-2010 in the municipalities of Altamira, Ciudad Madero and Tampico [20]. The generation rate considered was the Mexico’s national indicator of $2.7 \mathrm{~kg}$ WEEE per capita, which was estimated by the Mexican government through the National Institute of Ecology and Climate Change (INECC, acronym in Spanish) and developed in the work "Diagnostics Generation of WEEE in Mexico” [24] [25]. Similarly, estimates of WEEE generation developed by categories considered TVs, Personal Computers, Sound Devices, Landline and Mobile Phones, according to the percentages estimated in the Diagnosis of WEEE Generation in Mexico published in the year 2007 [24]. To prepare the WEEE flow diagram projected to 2030, the estimates of population were considered in the three municipalities and the five categories of EEE: TVs, Personal Computers, Sound Devices, Landline and Mobile Phones, using extrapolations in the pe- 
riod 2006 to 2030.

\subsection{Stage 2: Waste Stream Analysis}

An Analysis of the Flow of WEEE by 2030, taking into account five categories for the three municipalities, in order to observe trends by category and municipality generation of WEEE was performed. For the analysis of the waste stream Standard software was used for Material Flow Analysis STAN (Substance Flow Analysis) is a software that supports performing Material Flow Analysis (MFA) according to the Austrian standard ÖNORM S 2096 (Material Flow Analysis-Application in Waste Management) under consideration of data uncertainties [26]. Which handles the system Input-Process-Output, generated Waste Flow Analysis. Using a balance of inputs to outputs (2) [27].

$$
\text { Balance equation }: \text { inputs }=\text { outputs }+ \text { change in stock }
$$

\subsection{Stage 3: Description of Recycling Scenarios}

A literature review and interviews with managers of municipalities was conducted on official sources and with formal and informal companies who management WEEE in the area. Pictures of the current practices of management of WEEE were taken to integrate a portfolio of evidence. The observations were made based on the three traditional stages of solid waste management: collection and transfer; revaluation of raw materials or energy (by unitary physical operations or unitary chemical and biological processes); Treatment for disposal. It was revised the economic aspect of the local market of WEEE recycling.

\subsection{Stage 4: Description of Final Disposal Practices}

It was realized a field study and interviews with responsible of final disposal sites in the studied zone based on the criteria of Mexican Official Standard NOM-083-SEMARNAT-2003 Environmental protection specifications for site selection, design, construction, operation, monitoring, closure and additional works of a final disposal site for solid waste and special handling.

\section{Results and Discussion}

Table 1 shows the estimates of WEEE generation for the three municipalities according to the projection for the period 2006 to 2030 with a total generation of 53597.95 tons. For the 2013, the generation was estimated in 2040.38 tons. It can be appreciated that Tampico and Altamira are the municipalities who have a greater tendency to generate WEEE than Madero City, because they have a mayor population projection than Madero City. In Mexico the first diagnosis of WEEE generation was conducted in 2007, reporting a generation of 300,000 tons of WEEE in selected states of Mexican Republic located on the northern border of the country, as Nuevo Leon, Coahuila and Tamaulipas. This study reports an estimated of 15,799 tons of WEEE generation for Tamaulipas [24] [25]. The estimated generation in this study corresponds to the $13 \%$ of the total of the diagnosis of 2007.

Figure 3 display data in a graphical estimation of WEEE generation in tons per year in the municipalities concerned the trend in the increase of generation in Tampico and Altamira compared to Madero City is observed. It's displayed that the generation of WEEE in 2013 had a range of variability between 560 - 840 tons per municipality derived from population growth to the conditioning of WEEE generated. In addition, it exist a difference between collecting reports 96 tons in 2013 in the collection centers, against the 2040 tons estimated generation.

In addition, an estimate of WEEE generation was done by category, considering TVs, computers, audio equipment, fixed and mobile phones according to estimates in the national study percentages. In Table 2, the estimated TVs from WEEE were 1893.30 tons/year is observed. The trend for 2030 will be 2332.45 tons/year, meaning an increase of $111.51 \%$. An estimated growth of TVs compared to other electronic equipment is observed with an estimate for of 53204.14 tons/year by 2030. The process of technological obsolescence and renewal of equipment technology indicates that TVs of Cathode Ray Tubes (CRT) are discarded. Besides the change from analog to digital, under NOM-192-SCFI/SCT1-2013 Tele-communications these numbers from 2015 could increase when Mexico is scheduled to have total coverage of digital signal [28].

Figure 4 shows WEEE generation is projected and shown graphically by category increase. These categories 
Table 1. Projection estimated WEEE generation in the period 2006-2030.

\begin{tabular}{|c|c|c|c|c|}
\hline \multirow{2}{*}{ Year } & \multicolumn{3}{|c|}{ WEEE Generation (ton/year) } & \multirow{2}{*}{ Total } \\
\hline & Altamira & Madero City & Tampico & \\
\hline 2006 & 572.54 & 531.22 & 795.65 & 1899.41 \\
\hline 2007 & 583.62 & 535.45 & 801.07 & 1920.14 \\
\hline 2008 & 593.64 & 538.71 & 805.06 & 1937.41 \\
\hline 2009 & 610.35 & 547.97 & 818.01 & 1976.33 \\
\hline 2010 & 584.03 & 543.51 & 820.01 & 1947.56 \\
\hline 2011 & 610.53 & 549.83 & 824.06 & 1984.41 \\
\hline 2012 & 631.71 & 554.49 & 826.92 & 2013.12 \\
\hline 2013 & 650.18 & 559.27 & 830.93 & 2040.38 \\
\hline 2014 & 666.51 & 564.11 & 835.75 & 2066.38 \\
\hline 2015 & 681.11 & 568.94 & 841.10 & 2091.15 \\
\hline 2016 & 694.33 & 573.71 & 846.78 & 2114.82 \\
\hline 2017 & 706.46 & 578.40 & 852.66 & 2137.51 \\
\hline 2018 & 717.69 & 582.95 & 858.59 & 2159.22 \\
\hline 2019 & 728.15 & 587.33 & 864.44 & 2179.92 \\
\hline 2020 & 737.99 & 591.51 & 870.14 & 2199.64 \\
\hline 2021 & 747.35 & 595.51 & 875.70 & 2218.56 \\
\hline 2022 & 756.38 & 599.36 & 881.12 & 2236.86 \\
\hline 2023 & 765.10 & 603.04 & 886.34 & 2254.48 \\
\hline 2024 & 773.56 & 606.52 & 891.34 & 2271.41 \\
\hline 2025 & 781.78 & 609.79 & 896.07 & 2287.64 \\
\hline 2026 & 789.78 & 612.90 & 900.57 & 2303.25 \\
\hline 2027 & 797.57 & 615.86 & 904.89 & 2318.32 \\
\hline 2028 & 805.17 & 618.68 & 909.02 & 2332.86 \\
\hline 2029 & 812.58 & 621.35 & 912.94 & 2346.87 \\
\hline 2030 & 819.78 & 623.87 & 916.64 & 2360.29 \\
\hline Total & 17617.88 & 14514.27 & 21465.80 & 53597.95 \\
\hline
\end{tabular}

are considered in the diagnostic study of domestic waste generation, do not match the categories mentioned LGPGIR and neither the NOM-161-SEMARNAT-2011. It has already been mentioned that WEEE under Mexican law are handled as a group with other waste, such as construction and are considered special handling [18]. It is necessary to supplement the information WEEE generation in the study area considering the categories included in the NOM-161-SEMARNAT-2011 [19].

Figure 5 represents the stream flow of WEEE projected for 2030 for the study area. The three municipalities and the five categories of equipment for each municipality are considered. The greater tendency of TVs with $61 \%$, followed by the Sound Devices with $18 \%$, Personal Computers $17 \%$ is observed. Mobile Phones $2 \%$ with an increasing trend compared to Landline Phones with $1 \%$ with a decreasing trend. This shows the municipalities of Tampico and Altamira more WEEE generation TV's, in consideration of Ciudad Madero, because they are areas with socioeconomic mobility, industrial, and tourist projection. Also it shows the increase of Mobile 
Table 2. Estimation of WEEE generation by category for the period 2006-2030.

\begin{tabular}{|c|c|c|c|c|c|c|}
\hline \multirow{2}{*}{ Year } & \multicolumn{5}{|c|}{ WEEE Generation by Category (ton/year) } & \multirow[b]{2}{*}{ Total } \\
\hline & TVs & $\begin{array}{c}\text { Personal } \\
\text { Computers (PC) }\end{array}$ & $\begin{array}{c}\text { Sound Devices } \\
\text { (SD) }\end{array}$ & $\begin{array}{c}\text { Landline } \\
\text { Phones(LP) }\end{array}$ & $\begin{array}{l}\text { Mobile Phones } \\
\text { (MP) }\end{array}$ & \\
\hline 2006 & 1236.88 & 352.17 & 246.52 & 56.05 & 7.78 & 1899.41 \\
\hline 2007 & 1240.84 & 353.30 & 262.98 & 51.85 & 11.16 & 1920.14 \\
\hline 2008 & 1243.26 & 353.99 & 277.98 & 47.90 & 14.27 & 1937.41 \\
\hline 2009 & 1247.38 & 355.16 & 292.36 & 44.30 & 37.13 & 1976.33 \\
\hline 2010 & 1234.39 & 351.46 & 301.67 & 40.38 & 19.65 & 1947.56 \\
\hline 2011 & 1245.01 & 354.49 & 315.87 & 37.48 & 31.56 & 1984.41 \\
\hline 2012 & 1255.69 & 357.53 & 329.50 & 34.75 & 35.66 & 2013.12 \\
\hline 2013 & 1265.81 & 360.41 & 342.46 & 32.15 & 39.55 & 2040.38 \\
\hline 2014 & 1275.48 & 363.16 & 354.80 & 29.68 & 43.26 & 2066.38 \\
\hline 2015 & 1284.69 & 365.78 & 366.56 & 27.32 & 46.79 & 2091.15 \\
\hline 2016 & 1293.50 & 368.29 & 377.79 & 25.07 & 50.17 & 2114.82 \\
\hline 2017 & 1301.96 & 370.70 & 388.54 & 22.92 & 53.39 & 2137.51 \\
\hline 2018 & 1310.06 & 373.01 & 398.82 & 20.87 & 56.48 & 2159.22 \\
\hline 2019 & 1317.76 & 375.20 & 408.64 & 18.90 & 59.43 & 2179.92 \\
\hline 2020 & 1325.07 & 377.28 & 418.03 & 17.01 & 62.25 & 2199.64 \\
\hline 2021 & 1332.08 & 379.28 & 427.04 & 15.20 & 64.96 & 2218.56 \\
\hline 2022 & 1338.90 & 381.22 & 435.71 & 13.47 & 67.57 & 2236.86 \\
\hline 2023 & 1345.48 & 383.09 & 444.05 & 11.80 & 70.07 & 2254.48 \\
\hline 2024 & 1351.79 & 384.89 & 452.06 & 10.20 & 72.48 & 2271.41 \\
\hline 2025 & 1357.83 & 386.61 & 459.76 & 8.65 & 74.79 & 2287.64 \\
\hline 2026 & 1363.63 & 388.26 & 467.17 & 7.17 & 77.02 & 2303.25 \\
\hline 2027 & 1369.24 & 389.86 & 474.32 & 5.74 & 79.16 & 2318.32 \\
\hline 2028 & 1374.66 & 391.40 & 481.21 & 4.36 & 81.23 & 2332.86 \\
\hline 2029 & 1379.88 & 392.88 & 487.85 & 3.03 & 83.23 & 2346.87 \\
\hline 2030 & 1384.85 & 394.30 & 494.25 & 1.74 & 85.15 & 2360.29 \\
\hline Total & 32676.12 & 9303.71 & 9705.93 & 587.99 & 1324.19 & 53597.95 \\
\hline
\end{tabular}

Phones and WEEE trend away from Landline Phones, indicating growth in the acquisition of mobile telephony is shifting to mobile home or fixed.

In the study area, there are some mechanisms to recollection of WEEE, mainly in Tampico. However, it is common for the population regale, store, or discard as a municipal solid waste. There is a tendency to informal collectors in order to recover metals from WEEE, exposing harm to people and the environment. There is no site disposal of WEEE. To carry out a management plan is necessary to know the generation, stock revalorization and disposal. Therefore, the needs to identify the actions currently are undertaken in the study area regard the management of WEEE. In 2012, in the study only had three storage facilities located in Tampico. Currently, the town of Tampico has five collection centers, Madero City has planned to open a distribution center and Altamira is making efforts to open three collection centers, which have increased collection activity and collection in 


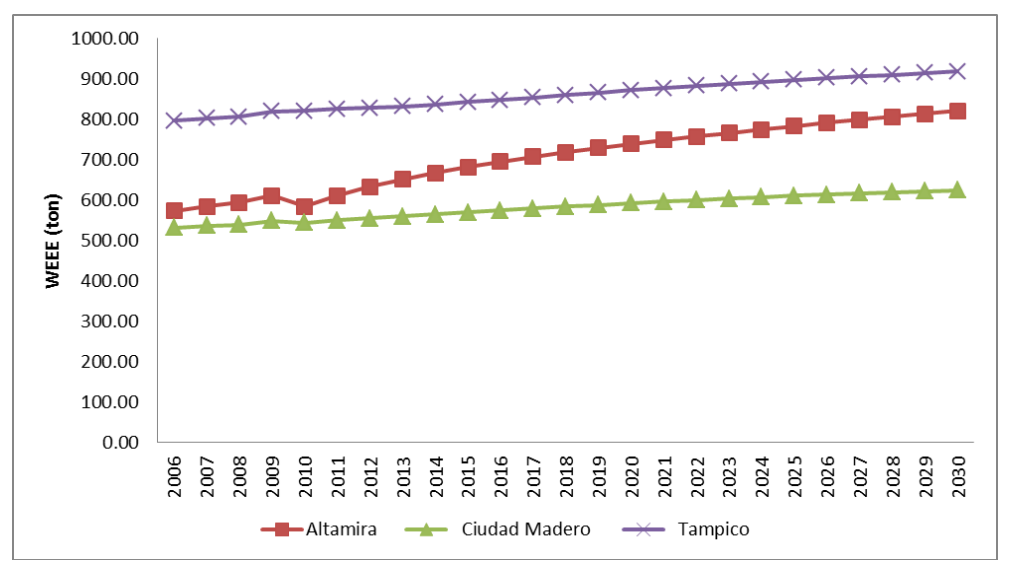

Figure 3. Projection of WEEE generation (ton/year) in the study area.

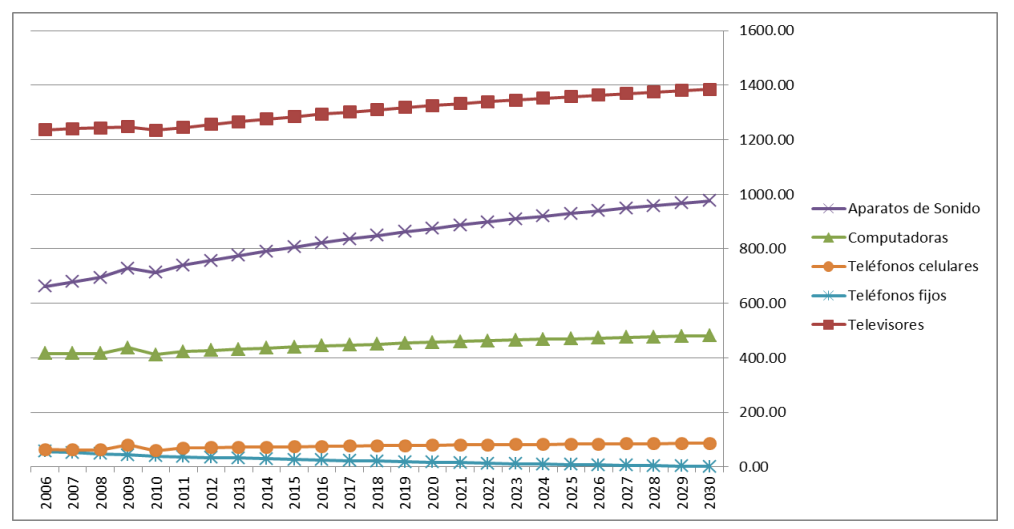

Figure 4. Estimation of WEEE generation by category in the study area.

Figure 6 are shown some of them. In addition, there are collection programs in different malls and telephone companies.

When massive collection by the municipality or schools participate in these events have temporary containers for collection. Also in certain subdivisions of the study area, have some permanent temporary containers to collect WEEE. Similarly, mobile phone companies in the study area have collection programs cellular equipment and accessories include containers for such WEEE. Regarding the transfer of WEEE during the period 2010 2012 the municipality of Tampico was a van without infrastructure, which adequate as mobile collection center for collection of WEEE. It is located at strategic points in the area and moves them to the collection centers in the municipality of Tampico, and two trucks are currently doing this type of transfer. No units separate collection of WEEE in the study area.

Regarding the revaluation of WEEE in the study area there are no companies providing treatment for this type of waste, all which is collected in the city of Tampico is transferred to a waste management company in the State of San Luis Potosi that treats revaluation to WEEE. This generates prospects for economic development for the area. There is an Informal collection and revalorization for a group of people known as "carretoneros" (wagonners), which were grouped in the "South Tamaulipas Union of Carretoneros", presenting a survey of 76 carts in the study area. There is no Site Disposal specialized in waste requiring special handling. WEEE deposited on public roads, especially on vacant lots or in lagoons has been found. The Site Final, official and unofficial arrangement, do not have records of the quantities of WEEE deposited, nor their origin or generating source.

There is no specific law for WEEE. Mexican laws are considered special waste handling, also in the NOM-161-SEMARNAT-2011 provides a general classification of WEEE [19]. However, both the law and the NOM make implicit the need to make a plan for managing this type of waste. Some of the preventive action is the principle of shared responsibility, which brings together manufacturers, institutions and society to minimize the generation of WEEE. Within the area there are six collection centers, distributed five Tampico and one in 


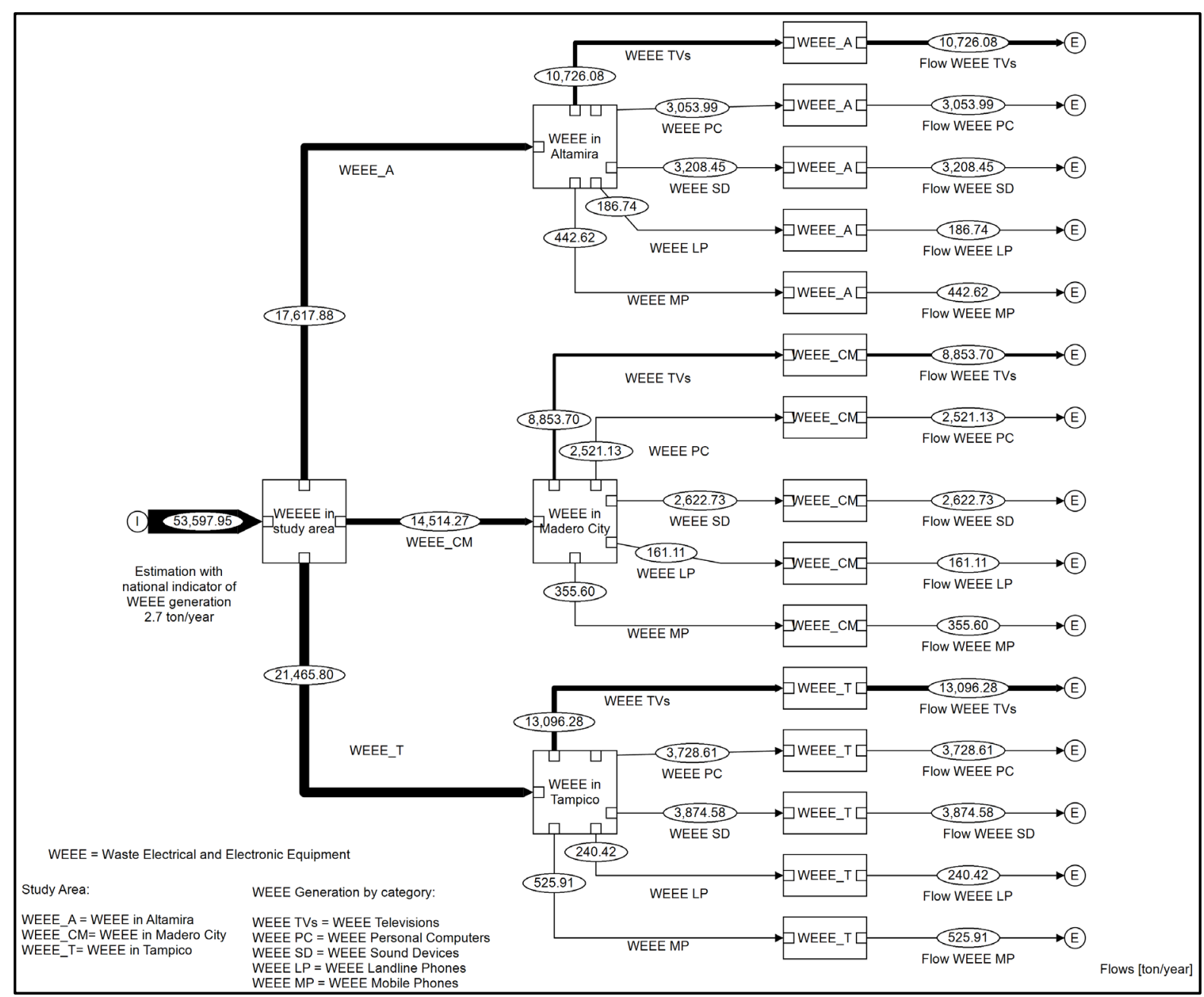

Figure 5. Flow analysis WEEE projected for 2030 for the study area.
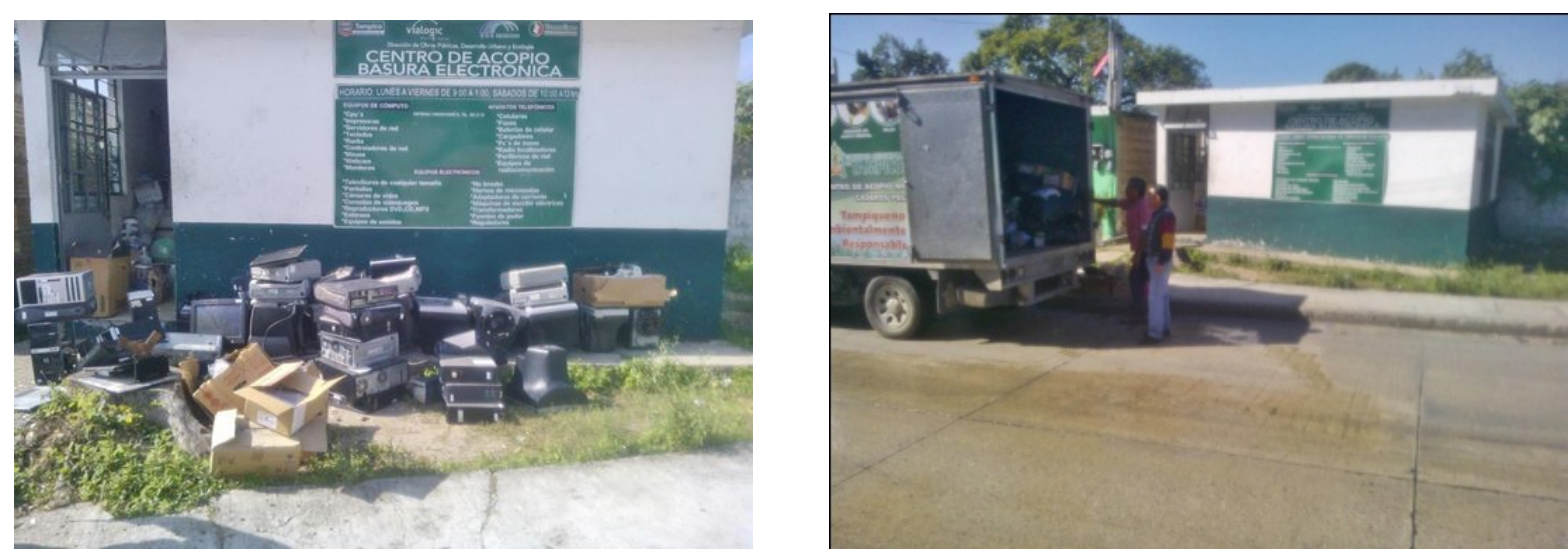

Figure 6. Collection centers in the study area.

Madero City. Moreover, the dissemination activities within the environmental education programs that give municipalities through Environmental department. There corrective policy instruments that monitors and controls the Federal Attorney for Environmental Protection (PROFEPA Spanish acronym), ranging from administrative and economic sanctions imposed on persons or institutions providing improper handling to WEEE. 


\section{Conclusions}

In the course of the study, the trend of socio-economic grows in urban areas of Southeast Tamaulipas, Tampico and Altamira mainly. Generation estimates show these two municipalities with an increase in the generation of WEEE in the period 2006 to 2030. Among studied categories, TVs represent the most important WEEE generation. Besides, decreasing telephone landlines had increased cellular phones waste generation. Trends in technological innovations and new telecommunications reforms are pressing for the use of new devices that are compatible with the new signals. This causes a renewal of electronic equipment and an increase in WEEE. Regarding the collection, there is just one vehicle that makes this function but it is not enough for the South Tamaulipas Conurbation needs. Informal WEEE gatherers have more contact with the generators and are partakers in the informal revalorization. It is important to note that within the area there are no companies that provide treatment for this kind of waste.

The generation indicators of WEEE used by authorities in Mexico have inconsistencies because the volume of waste observed in the collection centers and the disposal sites does not correspond with the estimated generation. Furthermore, reviewing the basis for the formulation of legislation management, programs that are not consolidated in the economic and social reality of the municipalities of Tampico, Madero and Altamira are observed. The existence of the principle of shared responsibility could generate preventive and corrective economic instruments, with a significant impact on stakeholders. Social involvement is relevant to the prevention and mitigation of the problem of WEEE, based on the development of an environmental culture factor. Finally, the prospects of this work are to develop elements for the formulation of a comprehensive management plan for WEEE, and the development of programs of implementation, monitoring and evaluation of the proposed short, medium and long for Metropolitan Areas South of Tamaulipas.

\section{References}

[1] Vega, O. (2012) Side Effects of Technological Obsolescence. Journal Faculty of Engineering, Pedagogic and Technological University of Colombia (UPTC), 21, 55-62.

[2] Cassia R.A., Moraes F.P.J. and Andrade G.R. (2006) The Growth of Waste Electrical and Electronic Equipment out of Use: The Environmental Impact They Represent. Journal of Engineering and Environmental Sciences: Research, Development and Practice, 1, 1-12.

[3] Ojeda-Benitez, S., Cruz-Sotelo, S.E., Velázquez, L., Santillán-Soto, N., Nuñez, M.Q., Cueto, O.R.G. andMarkus, W. (2013) Electrical and Electronic Waste in Northwest Mexico. Journal of Environmental Protection, 4, 405-410. http://dx.doi.org/10.4236/jep.2013.45048

[4] Ibrahim, F.B., Adie, D.B., Giwa, A.R., Abdullahi, S.A. and Okuofu, C.A. (2013) Material Flow Analysis of Electronic Wastes (E-Wastes) in Lagos, Nigeria. Journal of Environmental Protection, 4, 1011-1017. http://dx.doi.org/10.4236/jep.2013.49117

[5] Boeni, H., Silva, U. and Ott, D. (2008) E-Waste Recycling in Latin America: Overview, Challenges and Potential. Proceedings of the Global Symposium on Recycling, Waste Treatment and Clean Technology (REWAS 2008), Cancun, 12-15 October 2008, 1-10. http://www.ewasteguide.info/2008_Keynote_Boeni_REWAS

[6] Gavilán, A. (2011) Current Status of WEEE management in Mexico. Proceedings of Conference of the Parties to the Basel Convention, Cartagena, 17-21 October 2011, 4 p.

[7] Grant, K., Goldizen, F.C., Sly, P.D., Brune, M.N., Neira, M., van den Berg, M. and Norman, R.E. (2013) Health Consequences of Exposure to E-Waste: A Systematic Review. The Lancet Global Health, 1, e350-e361. http://dx.doi.org/10.1016/S2214-109X(13)70101-3

[8] Maheshwari, R.K., Rani, B. and Singh, U. (2013) Dribble of E-Waste: It’s Impact on Human Health \& Management Strategies for Sustainable Development. Research Journal of Chemical and Environmental Sciences, 1, 3-16.

[9] Zhang, K., Schnoor, J. and Zeng, E. (2012) E-Waste Recycling: Where Does It Go from Here? American Chemical Society; Environmental Science \& Technology, 46, 10861-10867. http://dx.doi.org/10.1021/es303166s

[10] Boeni, H., Silva, U. and Ott, D. (2009) Electronic Waste Recycling in Latin America. Overview, Challenges and Potential. In: Silva, U., Ed., Electronic Waste Management in Latin America, Ediciones Sur/Plataforma Relac Sur/Idrc, Santiago, 51- 66. http://www.web-resol.org/cartilha14/gestion_de_residuos_en_america_latina.pdf

[11] Gavilán-García, A., Alcántara-Concepción, V. and Gavilán-García, I. (2012) Life Cycle Analysis of Alternatives for the Management of Electronic Waste in Mexico. Proceedings of $V$ Congress of the Mesoamerican Association of Environmental Chemistry and Ecotoxicology (AMEQA), Aguascalientes, 25-28 July 2012, CD-ROM. 
[12] OECD (2012) OECD Internet Economy Outlook 2012. Organization for Economic Cooperation and Development, OECD Publishing, Paris, 296.

[13] DOF (1991) Basel Convention on the Control of Transboundary Movements of Hazardous Wastes and Their Disposal. Official Gazette, Mexico City.

[14] DOF (2004) Stockholm Convention on Persistent Organic Pollutants. Official Gazette, Mexico City.

[15] Babu, B.R., Parande, A.K. and Basha, C.A. (2007) Electrical and Electronic Waste: A Global Environmental Problem. Waste Management \& Research, 25, 307-318. http://dx.doi.org/10.1177/0734242X07076941

[16] Skinner, A., Dinter, Y., Lloyd, A. and Strothmann, P. (2010) The Challenges of E-Waste Management in India: Can India Draw Lessons from the EU and the USA? ASIEN, 117, 7-26.

[17] Zoeteman, B.C., Krikke, H.R. and Venselaar, J. (2010) Handling WEEE Waste Flows: On the Effectiveness of Producer Responsibility in a Globalizing World. The International Journal of Advanced Manufacturing Technology, 47, 415436. http://dx.doi.org/10.1007/s00170-009-2358-3

[18] DOF (2003) Decree on the General Law for the Prevention and Management of Waste, Official Gazette, 8 October 2003. Publisher Renovation, Mexico City, 7 June 2013.

[19] NOM-161-SEMARNAT-2011 (2013) Establishing the Criteria for Classifying Special Waste Handling and Determine Which Are Subject to the Management Plan; the Listing of Them, the Procedure for the Inclusion or Exclusion to That List; as Well as the Elements and Procedures for the Formulation of Management Plans. Official Mexican Standard. Official Journal.

[20] CONAPO (2013) Population Projections 2010-2050: From the Municipalities of Mexico from 2010 to 2030. National Population Council. http://www.conapo.gob.mx/

[21] PMOT (2011) Metropolitan Land Management Program of Altamira-Ciudad Madero, Tampico. http://www.imeplansurdetamaulipas.gob.mx/POT_Metropolitano.htm

[22] Armstrong J.S. and Collopy, F. (1993) Causal Forces: Structuring Knowledge for Time-Series Extrapolation. Journal of Forecasting, 12, 103-115. http://dx.doi.org/10.1002/for.3980120205

[23] Armstrong, J.S., Collopy, F. and Yokum, J.T. (2004) Decomposition by Causal Forces: A Procedure for Forecasting Complex Time Series. http://www.forecastingprinciples.com/paperpdf/Decomposition\%20by\%20Causal\%20Forces.pdf

[24] Moguel, G.J.R. (2007) Diagnosis of E-Waste Generation in Mexico. National Polytechnic Institute, Center for Interdisciplinary Research and Studies on Environment and Development and the National Institute of Ecology. Mexico City. http://www.inecc.gob.mx/descargas/diag_basura_electronica.pdf

[25] Acevedo, J., Rivas, E. and Carrillo, O. (2008) Diagnosis of Regional E-Waste Generation at the End of Its Useful Life in the Northeast Region of Mexico. Contract No INE/I3P-012/2007. INE-SEMARNAT y Center for Environmental Quality ITESM, Monterrey. http://www.inecc.gob.mx/descargas/sqre/res_electronicos_noreste_reporte_final.pdf

[26] The Standard for Material Flow Analysis (2012) Copyright by Institute for Water Quality, Resource and Waste Management. Vienna University of Technology, Vienna. http://www.stan2web.net/NetHelp/default.htm?turl=HTMLDocuments\%2FInstall.htm

[27] Cencic, O. and Rechberger, H. (2008) Material Flow Analysis with Software STAN. Journal of Environmental Engineering and Management, 18, 3.

[28] NOM-192-SCFI/SCT1-2013 (2013) Telecommunications Television and decoders Specifications. Official Mexican Standard. Official Journal. 
Scientific Research Publishing (SCIRP) is one of the largest Open Access journal publishers. It is currently publishing more than 200 open access, online, peer-reviewed journals covering a wide range of academic disciplines. SCIRP serves the worldwide academic communities and contributes to the progress and application of science with its publication.

Other selected journals from SCIRP are listed as below. Submit your manuscript to us via either submit@scirp.org or Online Submission Portal.
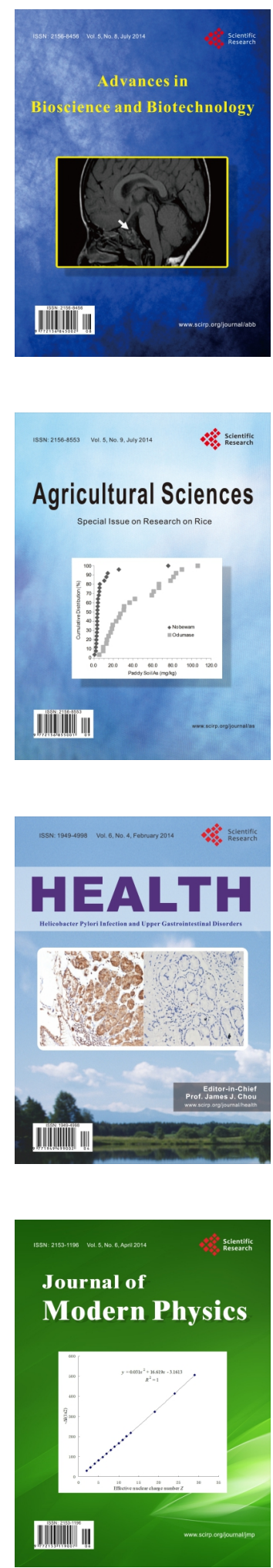
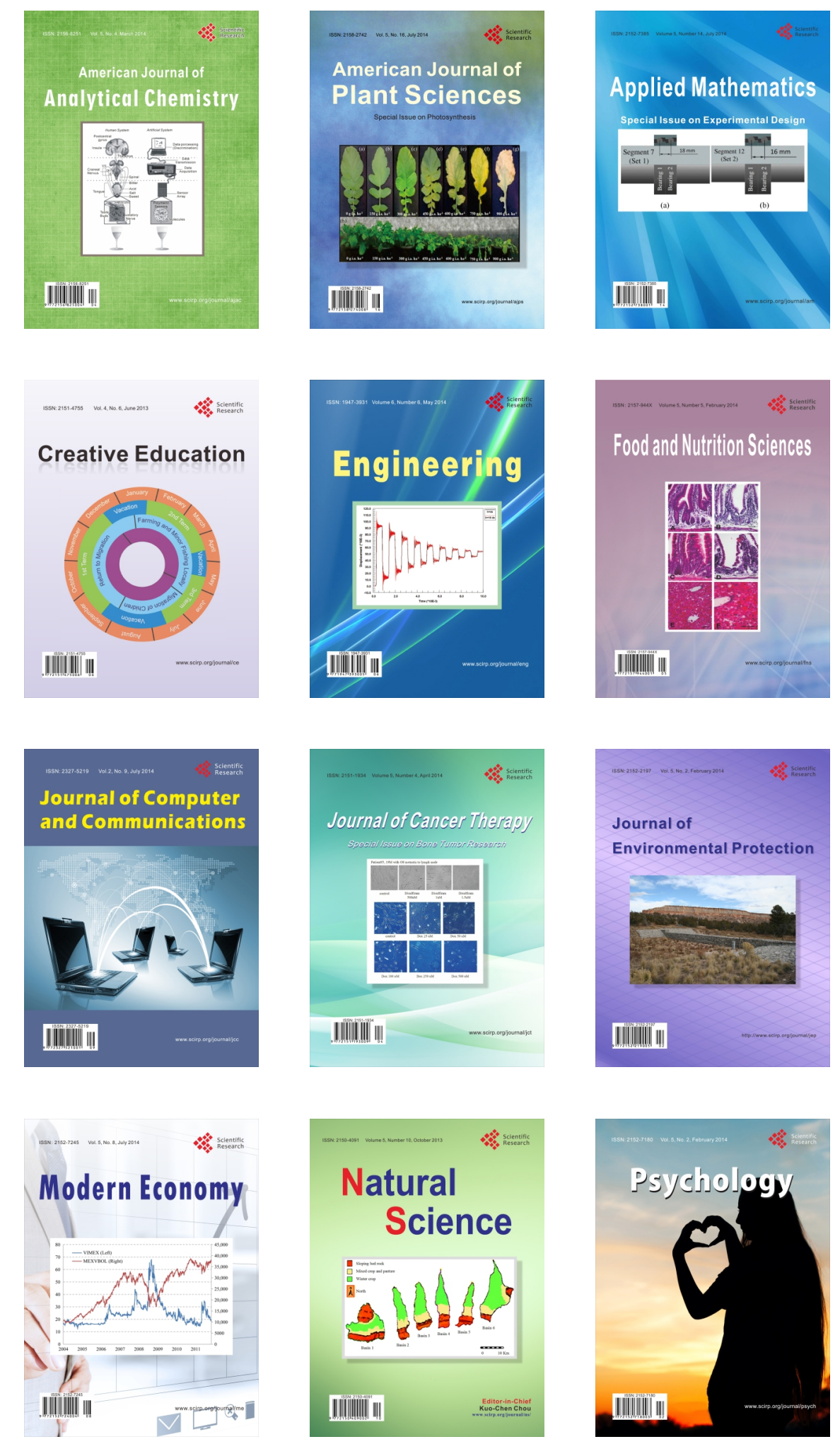